\title{
Early osmylids (Neurotera: Osmylidae) from the Lower-Middle Jurassic of Kyrgyzstan
}

\author{
Ранние осмилиды (Neurotera: Osmylidae) \\ из нижней-средней юры Киргизии
}

\author{
Alexander V. Khramov \\ Александр В. Храмов
}

\begin{abstract}
Borissiak Paleontological Institute, Russian Academy of Sciences, Profsoyuznaya st. 123, Moscow 117997, Russia. E-mail: a-hramov@yandex.ru.

Палеонтологический институт им. А.А.Борисяка РАН, Профсоюзная ул. 123, Москва 117997, Россия.
\end{abstract}

\section{KEY WORDS: Neuroptera, Osmylidae, Kempyninae, Jurassic, Kyrgyzstan, new species \\ КЛЮЧЕВЫЕ СЛОВА: Neuroptera, Osmylidae, Kempyninae, юра, Киргизия, новые виды}

ABSTRACT. Three new genera and five new species of osmylids are described from the late Early Jurassic - early Middle Jurassic of Kyrgyzstan: Tengriosmylus magnificus gen. et sp.n., Erlikosmylus obscurus gen. et sp.n., Mesosmylina shurabica $\mathbf{s p . n}$. and $M$. angusta sp. n., Sauktangida aenigmatica gen. et sp.n. The fossil record of Jurassic osmylids is briefly discussed. The proposal is made that $S$. aenigmatica gen. et sp.n. represents the ancestral condition of MA in hindwings of Osmylidae.

РЕЗЮМЕ. Из верхов нижней - низов средней юры Киргизии описываются три новых рода и пять новых видов осмилид: Tengriosmylus magnificus gen. et sp.n., Erlikosmylus obscurus gen. et sp.n., Mesosmylina shurabica sp.n. и M. angusta sp.n., Sauktangida aenigmatica gen. et sp.n. Кратко обсуждаются ископаемые находки Osmylidae юрского возраста. Выдвинуто предположение, что строение МА в заднем крыле $S$. aenigmatica gen. et sp.n. отражает предковое состояние этого признака у осмилид.

\section{Introduction}

Nowadays, family Osmylidae is distributed over all continents, except North America, and comprises about 200 species in 23 genera [Beutel et al., 2010]. It appeared in the fossil record in the Early Jurassic, but forms which are similar to osmylids and probably ancestral to them, are known from the Triassic. Such forms are placed by Makarkin et al. [2014] in the family Archeosmylidae Riek, 1953. According these authors, Archeosmylidae contains, besides the type species $\mathrm{Ar}$ cheosmylus pectinatus Riek, 1953 from the Upper Permian of Belmont (Australia), Babykamenia eskovi Ponomarenko et Shcherbakov, 2004 from the terminal Permian locality Babii Kamen' (Russia) and three species of Lithosmylidia Riek, 1955 from the Middle and Upper Triassic of Australia [Lambkin, 1988]. Makarkin et al. point out that this family is also represented by some undescribed lacewings from the Middle-Upper Triassic Madygen Formation (Kyrgyzstan). Archeosmylidae differs from Osmylidae mostly by non-pectinate $\mathrm{CuP}$ in the forewing, by more oblique branches of $\mathrm{CuA}$ and $\mathrm{A} 1$ and by smooth branches of Rs.

Only three osmylid species are known from the Lower Jurassic: Sogjuta Martynova, 1958, Petrushevskia Martynova, 1958 and Mesosmylina Bode, 1953. Makarkin et al. [2014] assigned all of them to the extinct subfamily Mesosmylininae.

The oldest osmylids, Sogjuta speciosa Martynova 1958 and Petrushevskia borisi Martynova 1958, were described from the locality Soguty. Lacewings, as well as other insects from Soguty, were found in the deposits of Dzhil formation, whose age is estimated to be the Early Lias based on the spore-pollen analysis [Aliev et al., 1981]. The total number of lacewings from Soguty is 30 , among them osmylids are the most numerous group (10 specimens, including holotypes). Despite of their relative abundance, osmylids from Soguty are not diverse, all of them likely belong to the genus Petrushevskia, except 1-2 representatives of the genus Sogjuta [pers. obs.]. The fragment of wing which presumably could be assigned to Lithosmylidia also was found in Soguty. The genus Petrushevskia is only known from the type locality, the other species of Sogjuta, S. shartegica Khramov, 2011, was described from the Upper Jurassic locality Shar-Teg. So this archaic genus existed throughout most of the Jurassic period.

Mesosmylina, the third known osmylid genus, which appeared in the Early Jurassic, comprises four species. M. exornata Bode, 1953 and M. falciferum Ansorge, 1996 were found in the Upper Lias of Braunschweig and Grimmen (Germany) respectively; M. mongolica Ponomarenko, 1984 was described from the Mongolian locality Oshin-Boro-Udzur-Ula (the upper Lower Jurassic). M. sibirica Ponomarenko, 1985 from the Middle Jurassic locality Kubekovo (Krasnoyarsk Krai, Rus- 
sia) is represented by the very incomplete wing, so the generic and even family affiliation of this species is under question.

The second-oldest representatives of the family after the above-mentioned Early Jurassic taxa are numerous and diverse osmylids from the Middle Jurassic (Bathonian) of Daohugou, China [Ren \& Yin, 2002; Ren \& Engel, 2007; Wang et al., 2009a, b, 2010, 2011; Yang et al., 2010]. Osmylids make up about half of all findings of Neuroptera in Daohugou, and approximately 50 percent of them belong to the extant subfamily Kempyninae [pers. obs.]. The osmylid fauna from the Upper Jurassic of Karatau, Kazakhstan (Upper Callovian to Kimmeridgian according [Doludenko \& Orlovskaya, 1976]) is the most similar to osmylids from Daohugou. Some osmylids from both localities belong to the same genera, the representatives of Kempyninae are the most abundant in Karatau as in Daohugou [Khramov, 2014]. But as opposed to Daohugou, osmylids from Karatau make up only $5-6 \%$ of the total number of lacewings.

Thus a significant gap exists in the fossil record of Osmylidae between the earliest relatively uniform Lower Jurassic forms belonging to extinct subfamily Mesos- mylininae and younger diverse faunas from Daohugou and Karatau, which consist mostly of representatives of extant subfamilies (Kempyninae, Gumillinae etc.). Fossil osmylids which are described in the present paper partially fill this gap. They were found in two Kirgiz localities of the similar age, Sai-Sagul and Sauk-Tanga.

The Jurassic locality Sai-Sagul (also known as Shurab III) is situated in Batken Province of Kyrgyzstan near the border with Tajikistan. All insects from Sai-Sagul (more than 3000 specimens) were found in the upper part of Sogul Formation. Analysis of leaf flora, spores and pollen demonstrates that the Sogul Formation is late Early Jurassic in age [Aliev et al., 1981], but there is no distinct border between Sogul Formation and overlying coal-bearing Samarkandek Formation of the early Middle Jurassic (Aalenian-Bajocian) age. Sukacheva and Rasnitsyn [2004] estimated the age of Sogul Formation as the late Early Jurassic to the early Middle Jurassic based on the fossil entomofauna. Locality Sauk-Tanga is situated about $15 \mathrm{~km}$ east of Sai-Sagul. Insects from this locality were found in the Jurassic deposits overlying the Triassic Madygen Formation [Dobruskina, 1995]. Stoneflies Mesoleuctra and corixoid aquatic bugs Shurabella, which are known from Sauk-Tanga, are quite
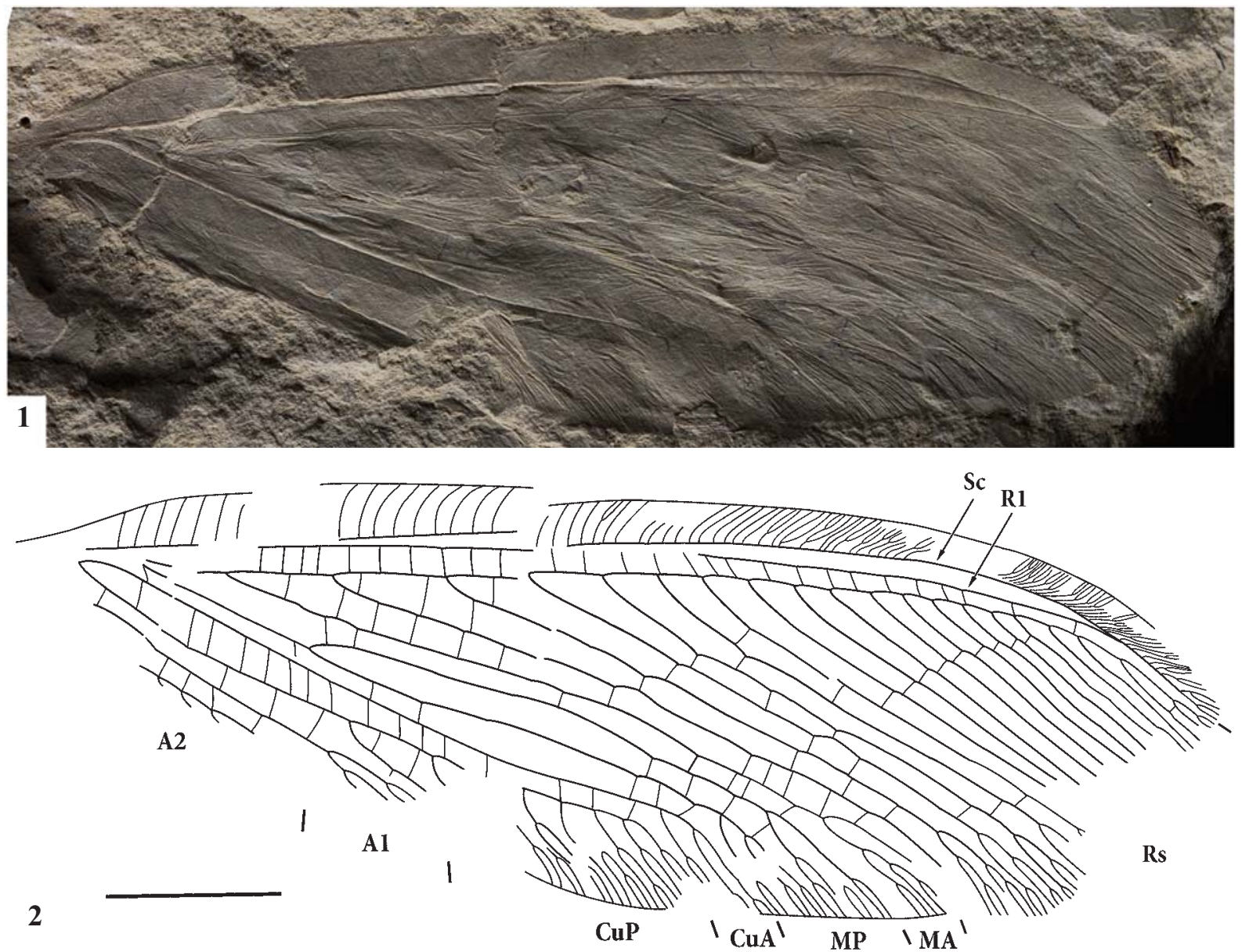

Figs 1-2. Tengriosmylus magnificus gen. et sp.n., Sai-Sagul, holotype PIN No. 2389/513, forewing. Scale bar $=5 \mathrm{~mm}$.

Рис. 1-2. Tengriosmylus magnificus gen. et sp.n., Сай-Сагул, голотип ПИН № 2389/513, переднее крыло. Длина масштабной линейки 5 мм. 
typical for Sai-Sagul [Shcherbakov, 2008]. This fact could indicate that the age of both localities is similar.

There are relatively few osmylids in Sai-Sagul: only 14 specimens (mostly fragmentary) could be assigned to Osmylidae (5-6\% of all lacewings from the locality). At the same time osmylids of Sai-Sagul are characterized by high diversity - it is possible to state, nevertheless the fragmentary preservation, that nearly all of them belong to different taxa. For example, the new taxa described herein are each represented by only single specimens. There are large osmylids (as Tengriosmylus magnificus gen. et sp.n; forewing length $34 \mathrm{~mm}$ ) in Sai-Sagul, while all the Early Jurassic members of the family are small (forewing length less than $16 \mathrm{~mm}$ ), like Triassic Archeosmylidae. Tengriosmylus and Erlikosmylus gen.n. probably belong to the different subfamilies than the earliest osmylids (i.e. not to Mesosmylininae), but it will be too early to establish new subfamilies for them until examination of additional material. Single osmylid from Sauk-Tanga, Sauktangida aenigmatica gen. et sp.n., is large in size (forewing length more than $40 \mathrm{~mm}$ ), even in comparison with recent Osmylidae. Sauktangida seems to be close to extant Kempyninae, the most abundant group of osmylids in the Middle and Late Jurassic. Thus it is possible to make a conclusion, that osmylid fauna of Sai-Sagul and Sauk-Tanga is intermediate between the Early Jurassic osmylids and osmylids from the Middle and Upper Jurassic.

\section{Material and methods}

This study is based on specimens that are housed in the fossil insect collection of the Paleontological Institute (PIN) of the Russian Academy of Science in Moscow, Russia.

The specimens were examined using a Leica MZ 9.5 and a MPS-2 dissecting microscope. Line drawings were performed using Adobe Photoshop CS3 and photographs were taken by Leica M165C stereomicroscopes. The wing venation terminology follows Carpenter [1943].

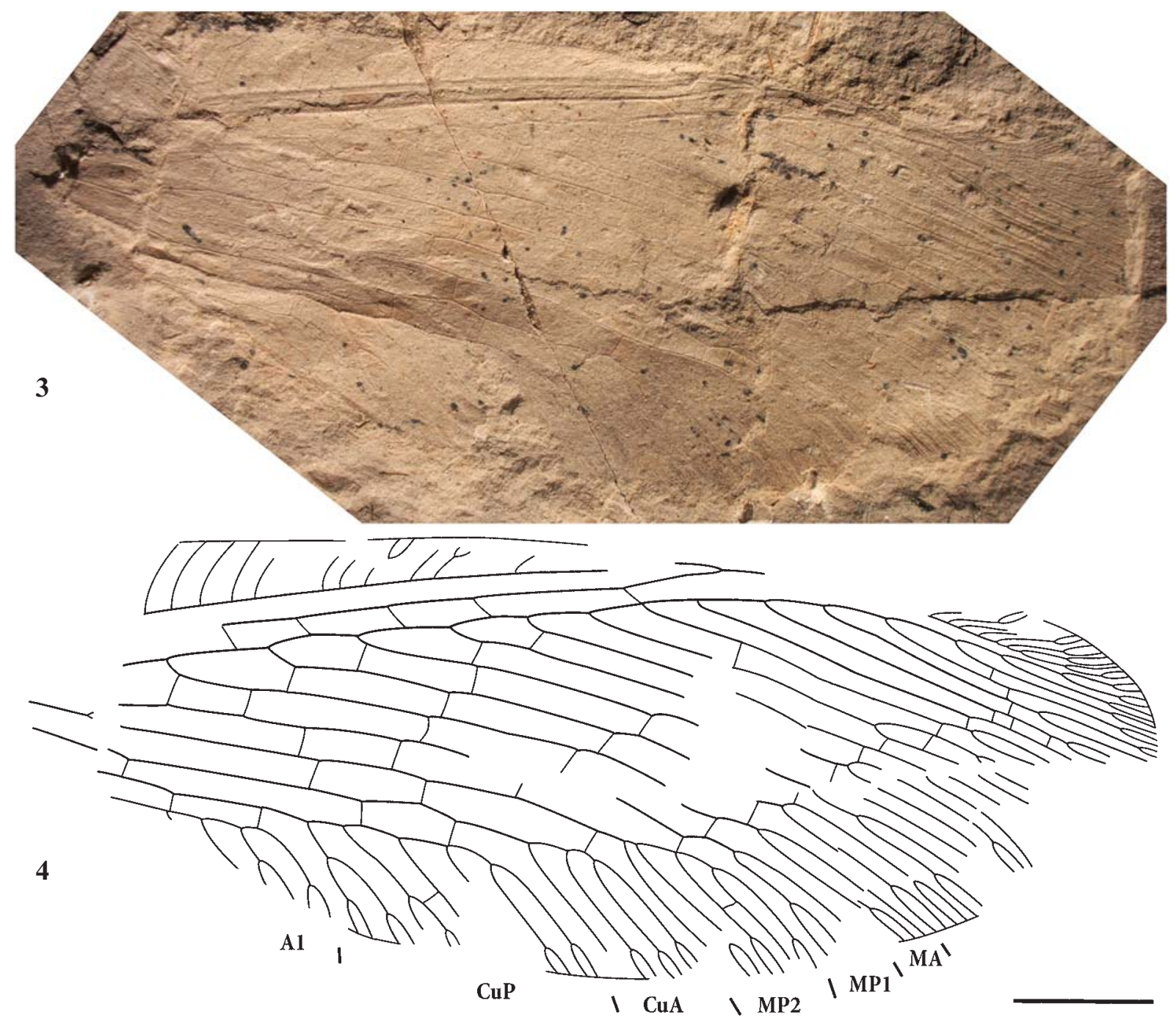

Figs 3-4. Erlikosmylus obscurus gen. et sp.n., Sai-Sagul, holotype PIN No. 1724/325, forewing. Scale bar $=3 \mathrm{~mm}$

Рис. 3-4. Erlikosmylus obscurus gen. et sp.n., Сай-Сагул, ПИН № 1724/325, переднее крыло. Длина масштабной линейки 3 мм. 


\section{Systematic paleontology}

\section{Order Neuroptera Linnaeus, 1758 \\ Family Osmylidae Leach, 1815 \\ Tengriosmylus Khramov, gen.n.}

TYPE SPECIES: T. magnificus sp.n.

DIAGNOSIS. Forewing elongate, crossveins abundant in proximal part of wing and between R1 and Rs along total wing length, 3 gradate series of crossveins present in distal part of wing, CuA almost unbranched, A1 and A2 dichotomously and pectinately branched respectively.

COMPARISON. May be distinguished from other osmylids by dichotomously branched A1, which goes under the branches of CuP. All other genera of Osmylidae have pectinate $\mathrm{A} 1$ in forewings.

ETYMOLOGY. From Tengri, the chief deity in Turkic mythology, and the genus Osmylus. Gender masculine.

\section{Tengriosmylus magnificus Khramov, sp.n.} Figs 1-2.

MATERIAL. Holotype PIN No. 2389/513, nearly complete forewing, part and counterpart.

LOCALITY AND HORIZON. Sai-Sagul, $12 \mathrm{~km}$ southwest of town Shurab, Batken Province of Kyrgyzstan, Sogul Formation, the late Early Jurassic to early Middle Jurassic.

DESCRIPTION. Forewing: costal space narrow, MP forked at about level of separation of first branch of Rs from Rs, crossveins abundant between $\mathrm{CuA}$ and $\mathrm{CuP}, \mathrm{CuA}$ with 3 branches, as well as MP2, CuP with no more than 8 branches, first branches of $\mathrm{CuP}$ inclined at an acute angle to stem of $\mathrm{CuP}$, last ones - at nearly right angle, A1 starts to branch under first branch of $\mathrm{CuP}$.

MEASUREMENTS: forewing length $34 \mathrm{~mm}$, maximal forewing width $-11 \mathrm{~mm}$.

ETYMOLOGY. From the Latin word magnificus, meaning "eminent".

\section{Erlikosmylus Khramov, gen.n.}

TYPE SPECIES: E. obscurus sp.n.

DIAGNOSIS. Forewing: crossveins scarce, most of them arranged in three gradate series, first series nearly vertical, located in proximal part of wing, second and third are parallel to each other and to hind margin of wing; Sc and R1 fused at the beginning of the last third of wing; MP forked distally to point of separation of MA from RS; $\mathrm{CuP}$ has much more branches, than $\mathrm{CuA}$.

COMPARISON. Erlikosmylus is similar to members of subfamily Protosmylinae by scarcity of crossveins, but differs from them by developed $\mathrm{CuP}$ in forewings, which branched more abundantly than $\mathrm{CuA}$.

ETYMOLOGY. From Erlik, the god of underworld in Turkic mythology, and the genus Osmylus. Gender masculine.

\section{Erlikosmylus obscurus Khramov, sp.n. Figs 3-4.}

MATERIAL. Holotype PIN No. 1724/325, incomplete forewing, part and counterpart.

LOCALITY AND HORIZON. Sai-Sagul, $12 \mathrm{~km}$ southwest of town Shurab, Batken Province of Kyrgyzstan, Sogul Formation, the late Early Jurassic to early Middle Jurassic.
DESCRIPTION. Forewing: costal space narrowed significantly at about half its length, Rs with 12 branches, branches of MP2 more numerous than branches of $\mathrm{CuA}, \mathrm{CuP}$ with 6 branches, A1 with no less than 4 branches.

MEASUREMENTS: forewing length, as preserved, 24 $\mathrm{mm}$, maximal forewing width $-9 \mathrm{~mm}$.

ETYMOLOGY. From the Latin word obscurus, meaning "obscure".

\section{Genus Mesosmylina Bode, 1953}

\section{Mesosmylina shurabica Khramov, sp.n.} Figs 5-6.

MATERIAL. Holotype PIN No. 3073/460, nearly complete forewing, part and counterpart.

LOCALITY AND HORIZON. Sai-Sagul, 12 km southwest of town Shurab, Batken Province of Kyrgyzstan, Sogul Formation, the late Early Jurassic to early Middle Jurassic.

DESCRIPTION. Forewing: Rs with 16 branches, three long gradate series of crossveins situated in distal part of wing; MP forked distally to point of separation of MA from $\mathrm{RS}, \mathrm{CuA}$ with 4-5 branches that connected with each other by one row of crossveins, branches of $\mathrm{CuP}$ occupied less area than branches of $\mathrm{CuA}, \mathrm{A} 1$ pectinate, $\mathrm{A} 2$ with 2-3 branches.

MEASUREMENTS: forewing length $22 \mathrm{~mm}$, maximal forewing width $-7 \mathrm{~mm}$.

COMPARISON. M. shurabica is larger than other members of genus (forewing length of $M$. exornata, the largest of them, is $17 \mathrm{~mm}$ ). M. shurabica could be distinguished from from M. mongolica and M. exornata by MP, which is forked distally to the of separation of MA from RS; from M. falcifer$u m$ by the presence of crossveins between branches of $\mathrm{CuA}$ and by the bigger size (forewing length of $M$. falciferum is $13 \mathrm{~mm}$ ).

ETYMOLOGY. Derived from the name of the locality Shurab III (Sai-Sagul).

\section{Mesosmylina angusta Khramov, sp.n. Figs 7-8.}

MATERIAL. Holotype PIN No. 2389/480, incomplete forewing.

LOCALITY AND HORIZON. Sai-Sagul, $12 \mathrm{~km}$ southwest of town Shurab, Batken Province of Kyrgyzstan, Sogul Formation, the late Early Jurassic to early Middle Jurassic.

DESCRIPTION. Forewing: three long gradate series of crossveins situated in distal part of wing and one - in proximal part, MP unforked, CuA with 4 branches that connected with each other by one row of crossveins, branches of $\mathrm{CuA}$ occupied about the same area as branches of $\mathrm{CuP}$ (in quantity of 5). A1 pecinate, A2 with 3 branches.

MEASUREMENTS: forewing length, as preserved, 16 $\mathrm{mm}$, estimated complete length $19-20 \mathrm{~mm}$.

COMPARISON. $M$. angusta is very similar to $M$. shurabica from the same locality, differs from it by smaller size, additional gradate series of crossveins and unforked MP in forewings. Except $M$. angusta, no other members of Mesosmylina have unforked MP. This trait is not typical for the most of osmylids. Representatives of recent subfamilies Stenosmylinae, Porisminae and Eidoporisminae have such one branched MP, but they retain the distal bifurcation of MP near the wing margin, which is absent in forewings of $M$. angusta.

ETYMOLOGY. From the Latin word angustus, meaning "narrow".

Figs 5-8. Mesosmylina, Sai-Sagul, forewings: 5-6 - M. shurabica sp.n., holotype PIN № 3073/460; 7-8 - M. angusta sp.n., holotype PIN No. 2389/480. Scale bar $=3 \mathrm{~mm}$.

Рис. 5-8. Mesosmylina, Сай-Сагул, передние крылья: 5-6 - M. shurabica sp.n., голотип ПИН № 3073/460; 7-8 — M. angusta sp.n., голотип ПИН № 2389/480. Длина масштабной линейки 3 мм. 

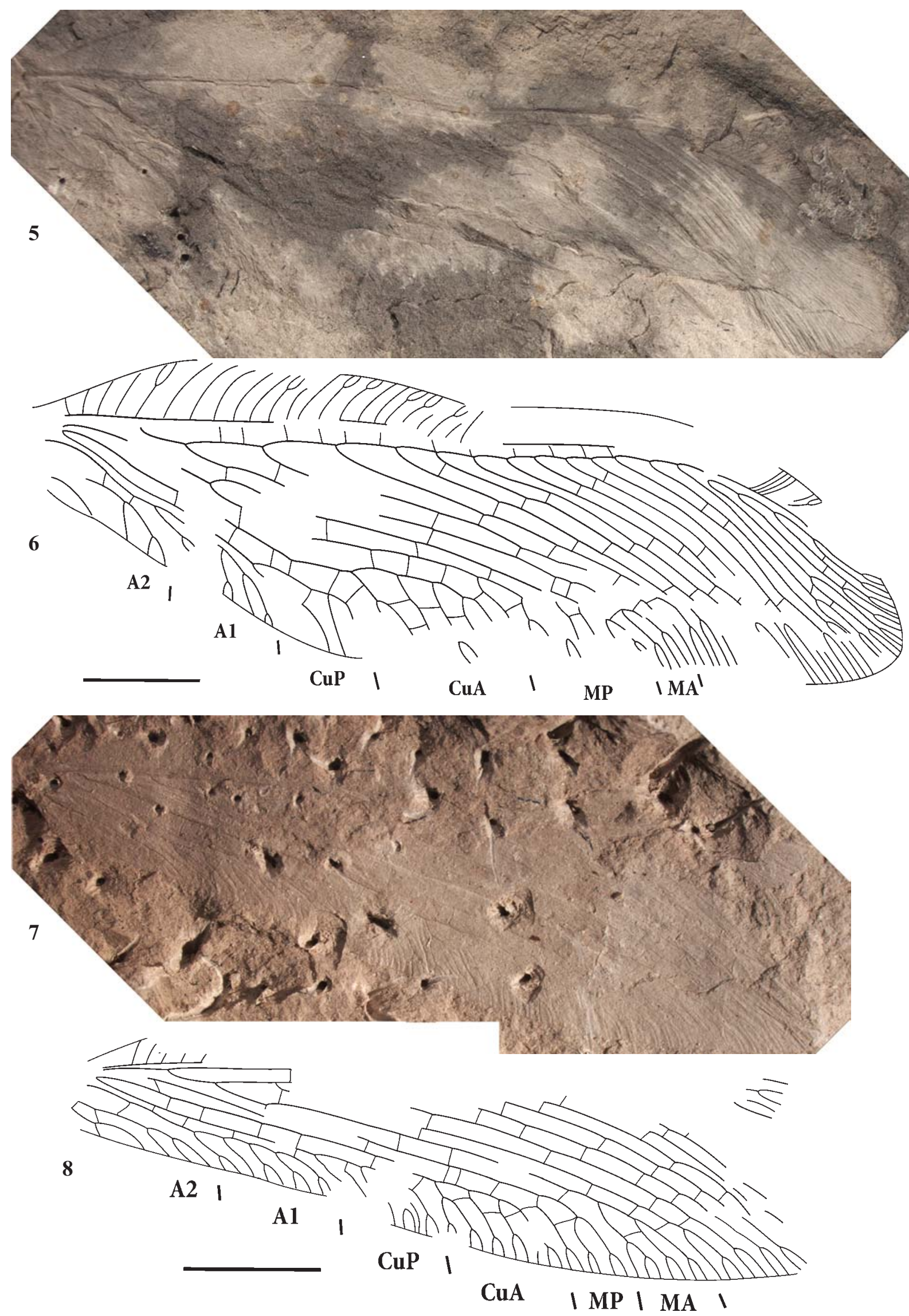
Sauktangida Khramov, gen.n.

TYPE SPECIES: S. aenigmatica sp.n.

DIAGNOSIS. Large wide wings (length more than 40 $\mathrm{mm}$ ) with abundant crossveins in proximal part, costal veinlets could be forked and connected with each other by one row of crossveins in some sections of costal space, branches of $\mathrm{CuA}$ and $\mathrm{CuP}$ long, sometimes multi-branched, here and there connected by a few crossveins. Hindwing: $2-3$ rows of cells situated in space between MP1 and MP2, distal part of MP2 strongly branched, A2 pectinate.

COMPARISON. Sauktangida looks slightly unusual in comparison with other osmylids because of wide wings. Nev-
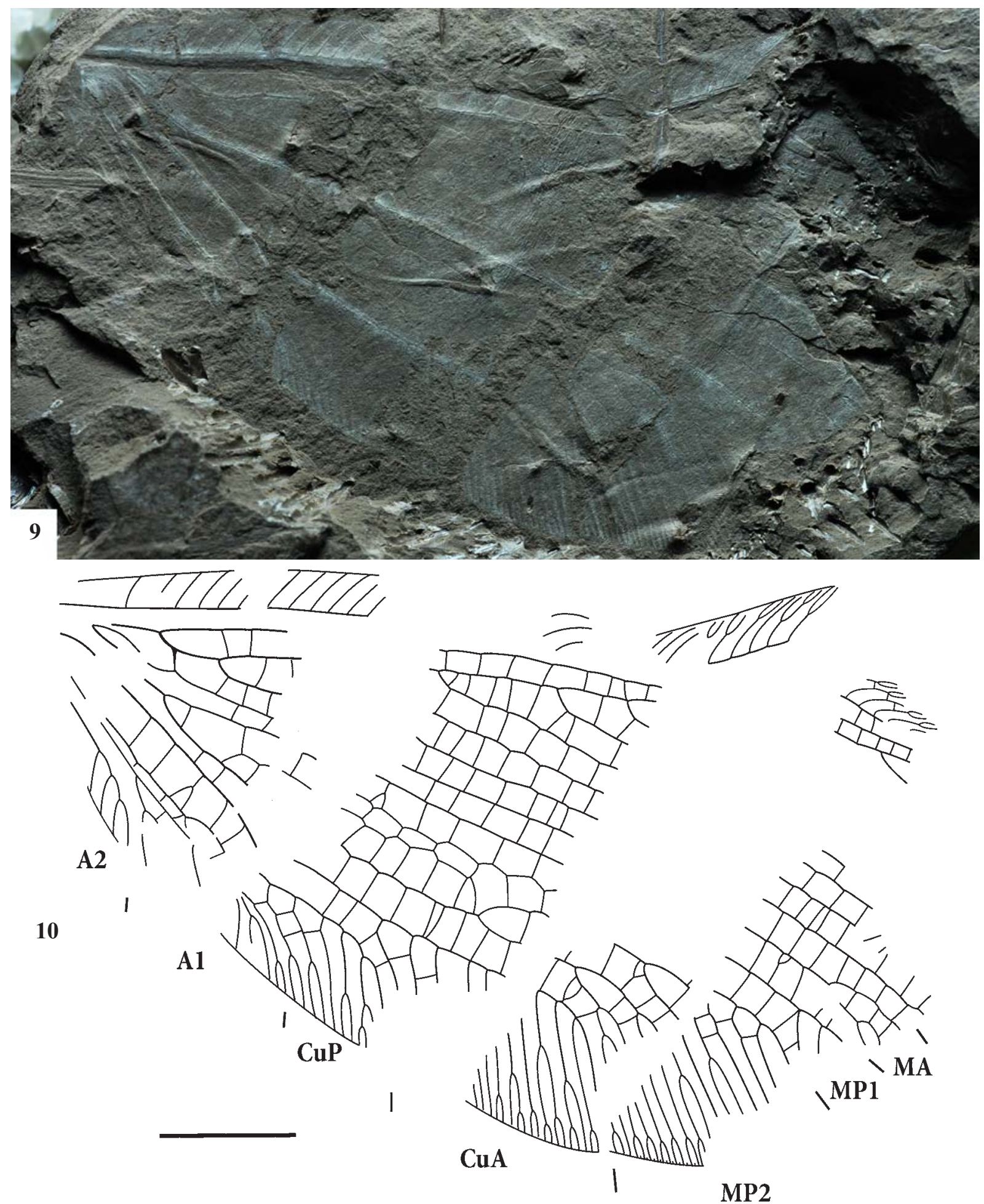

Figs 9-10. Sauktangida aenigmatica gen. et sp.n., Sauk-Tanga, holotype PIN No. 5346/71, hindwing. Scale bar $=5 \mathrm{~mm}$.

Pис. 9-10. Sauktangida aenigmatica gen. et sp.n., Саук-Таньга, голотип ПИН № 5346/71, заднее крыло. Длина масштабной линейки 5 мм. 
ertheless belonging of Sauktangida to Osmylidae is corroborated by the presence of pectinated $\mathrm{CuA}, \mathrm{CuP}, \mathrm{A} 1$ and $\mathrm{A} 2$. The ratio of sizes of branching patterns of $\mathrm{CuA}$ and $\mathrm{CuP}$ in hindwing of Sauktangida is the same as in hindwings of other osmylids. It seems that Sauktangida is the closest to Kempyninae. Some fossil (Euporismites balli Tillyard, 1916 from the Paleocene of Australia and Jurakempynus bellatulus Wang et al., 2011 from the Middle Jurassic of Daohugou) and recent kempynins have MP2 in hindwings, which is strongly branched in its distal part, like MP2 of Sauktangida. Recent Australian genus Clydosmylus New, 1983, Arbusella Khramov, 2014 from the Upper Jurassic of Karatau [Khramov, 2014], Jurakempynus Wang et al., 2011 from the Daohugou [Wang et al., 2011], Karatau and the Upper Jurassic of Mongolia [Khramov, 2014], as well as Sauktangida, are characterized by the presence of 2-3 rows of cells between MP1 and MP2 in hindwings. So it could not be excluded that Sauktangida is the sister taxon of Kempyninae or the member of this subfamily.
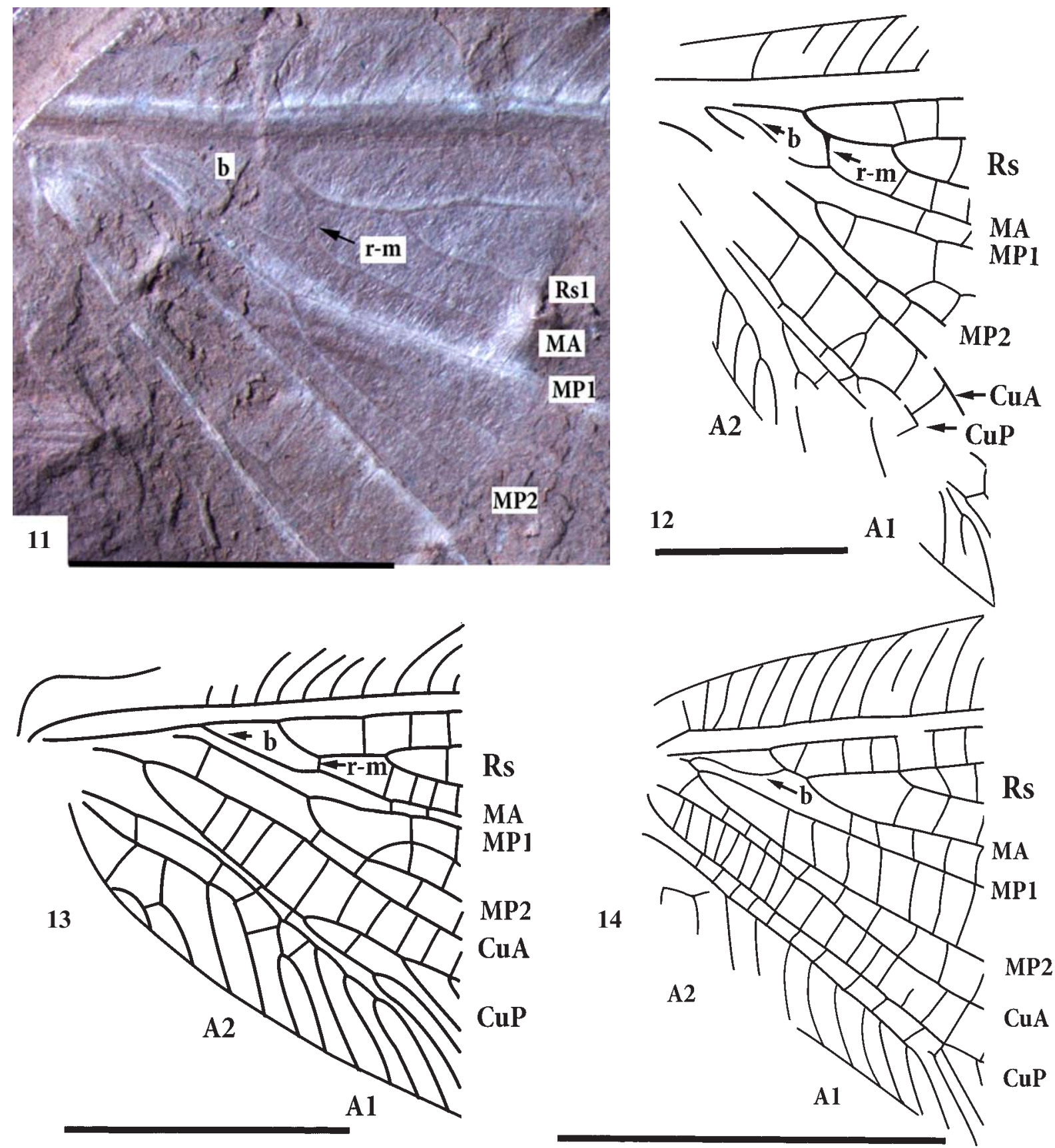

Fig. 11-14. MA in hindwings of osmylids: 11-12-Sauktangida aenigmatica gen. et sp.n., holotype; 13-Jurakempynus bellatulus Wang et al. 2011 (Kempyninae), Middle Jurassic of Daohugou (China), holotype [from Wang et al., 2011]; 14 — Euporismites balli Tillyard, 1916 (Kempyninae), Palaeocene of Queensland (Australia) [from Lambkin, 1987]; b — basal part of MA. Scale bars $=5$ mm (everywhere).

Рис. 11-14. МА в задних крыльях осмилид: 11-12 - Sauktangida aenigmatica gen. et sp.n., голотип; 13 - Jurakempynus bellatulus Wang et al. 2011 (Kempyninae), средняя юра Даохугоу (Китай), голотип [из Wang et al., 2011]; 14 — Euporismites balli Tillyard, 1916 (Kempyninae), палеоцен Квинсленда (Австралия) [из Lambkin, 1987]; b — основание МА. Длина масштабных линеек везде 5 мм. 
ETYMOLOGY. Derived from the name of the type locality. Gender feminine.

REMARKS. Osmylids with wide wings looking similar to Sauktangida are also present among lacewings from Daohugou [pers.obs.]. Fragments of wings, which could belong to Sauktangida, occur in the collection of lacewings from Sai-Sagul, but the fragmentary preservation precludes their taxonomic attribution.

\section{Sauktangida aenigmatica Khramov, sp.n.} Figs 9-12.

MATERIAL. Holotype PIN No. 5346/71, the proximal part of hindwing, part and counterpart.

LOCALITY AND HORIZON. Sauk-Tanga, $70 \mathrm{~km}$ southeast of Khujand (former Leninabad), Osh Province of Kyrgyzstan, Jurassic deposits overlying of Madygen Formation, late Early Jurassic to early Middle Jurassic.

DESCRIPTION. Hindwing: MA not fused with Rs, branches of MP2 occupied about the same area as branches of $\mathrm{CuA}, 3$ rows of cells situated between MP1 and MP2 until bifurcation of the latter, stems of $\mathrm{CuP}$ and $\mathrm{A} 1$ are close to each other, A2 with no more than 4 branches.

MEASUREMENTS: hindwing length, as preserved, 32 $\mathrm{mm}$, maximal hindwing width $18 \mathrm{~mm}$, estimated complete length 40-42 mm.

REMARKS. MA in hindwing of Sauktangida aenigmat$i c a$, in contrast to the most of lacewings, is not fused with Rs and retains the connection with MP (Figs 11-12). As regards hindwings of some osmylids, the base of MA, after the fusion of MA with Rs, was transformed into a short longitudinal vein (vein "b", [Carpenter, 1943]), which joins the common stem of Rs (see Fig. 14). The first stage of this fusion was beginning in hindwings of Sauktangida, as the thickened crossvein $\mathrm{r}-\mathrm{m}$ demonstrates. This crossvein served probably as a connecting link between MA and R, when MA "switched" to Rs from MP. Interestingly, that Kempyninae, the closest relatives of Sauktangida among Osmylidae, in some cases retain shortcut crossvein r-m (see Fig. 13), thereby not completing the fusion of MA with Rs. Thus Sauktangida represents the ancestral condition of MA in hindwings of other osmylids.

ETYMOLOGY. From the Latin word aenigmaticus, meaning "enigmatic".

ACKNOWLEDGEMENTS. This study was supported by the scientific program "Evolution of the Biosphere" and the RFFI grant No. 13-04-01839A. I thank A. P. Rasnitsyn and A. G. Ponomarenko (Borissiak Paleontological Institute, Russia, Moscow) for helpful advices.

\section{References}

Aliev M.M., Genkina R.Z., Dubrovskaya E. N., Nikishova V.M 1981. [Jurassic continental deposits of Eastern Central Asia (dating, subdivision, correlation)]. Moscow: Nauka. 188 pp. [in Russian]

Ansorge J. 1996. Insekten aus dem oberen Lias von Grimmen (Vorpommern, Norddeutschland) // Neue Paläontologische Abhandlungen. Bd.2. $132 \mathrm{~S}$.
Beutel R.G., Zimmermann D., Krauß M., Randolf S., Wipfler B. 2010. Head morphology of Osmylus fulvicephalus (Osmylidae, Neuroptera) and its phylogenetic implications // Organisms Diversity \& Evolution. Vol.10. No.4. P.311-329.

Bode A. 1953. Die Insektenfauna des ostniedersächsischen Oberen Lias // Palaeontographica. Bd.103A. S.1-375.

Carpenter F.M. 1943. Osmylidae of the Florissant shales, Colorado (Insecta-Neuroptera) // American Journal of Science. Vol.241. P.753-760.

Dobruskina I.A. 1995. Keuper (Triassic) Flora from Middle Asia (Madygen, Southern Fergana) // New Mexico Museum of Natural History and Science Bulletin. Vol.5. P.1-49.

Doludenko M.P., Orlovskaya E.R. 1976. [Jurassic Flora of Karatau]. Moscow: Nauka. 264 pp. [in Russian]

Khramov A. V. 2011. Two New Lacewings (Neuroptera) from the Upper Jurassic Locality Shar-Teg (Mongolia) // Paleontological Journal. Vol.45. No.2. P.174-178.

Khramov A. V. 2014.[ Osmylidae (Insecta: Neuroptera) from the Upper Jurassic of Asia] // Paleontological Journal. No.3. P.7786 [in Russian].

Lambkin K.J. 1987. A re-examination of Euporismites balli Tillyard from the Palaeocene of Queensland (Neuroptera: Osmylidae: Kempyninae) // Neuroptera International. Vol.4. P.295-300.

Lambkin K. J. 1988. A re-examination of Lithosmylidia Riek from the Triassic of Queensland with notes on Mesozoic 'osmylidlike' fossil Neuroptera (Insecta: Neuroptera) // Memoirs of The Queensland Museum. Vol.25. P.445-458.

Makarkin V.N., Yang Q., Ren D. 2014. A new basal osmylid neuropteran insect from the Middle Jurassic of China linking Osmylidae to the Permian-Triassic Archeosmylidae // Acta Palaeontologica Polonica. Vol.59. No.1. P.209-214.

Martynova O.M. 1958. [New Insects from the Permian and Mesozoic Deposits of the USSR] // Materialy k "Osnovam Paleontologii". Vol.2. P.69-94 [in Russian].

Ponomarenko A.G. 1984. Lacewings from the Jurassic of Eastern Asia // Paleontological Journal. Vol.18. No.3. P.64-73.

Ponomarenko A.G. 1985. [Lacewings from the Jurassic of Siberia and Western Mongolia] // Rasnitsyn A.P. (ed). Yurskie nasekomye Sibiri i Mongolii. Moscow: Nauka. P.91-96 [in Russian].

Ren D., Yin J.-C. 2002. [A new Middle Jurassic species of Epiosmylus from Inner Mongolia, China (Neuroptera: Osmylidae)] // Acta Zootaxonomica Sinica. Vol.27. No.2. P.274-277 [in Chinese, with English summary].

Ren D., Engel M.S. 2007. A split-footed lacewing and two epiosmylines from the Jurassic of China (Neuroptera) // Annales Zoologici (Warszawa). Vol.57. No.2. P.211-219.

Shcherbakov D.E. 2008. Madygen, Triassic Lagerstätte number one, before and after Sharov // Alavesia. Vol.2. P.113-124.

Sukacheva I.D., Rasnitsyn A.P. 2004. Jurassic insects (Insecta) from the Sai-Sagul locality (Kyrgyzstan, Southern Fergana) // Paleontological Journal. Vol.38. No.2. P.182-186.

Wang Y.J., Liu Z.Q., Ren D. 2009a. A new fossil lacewing genus from the Middle Jurassic of Inner Mongolia, China (Neuroptera: Osmylidae) // Zootaxa. Vol.2034. P. 65-68.

Wang Y.J., Liu Z.Q., Ren D. 2009b. A new fossil lacewing genus and species from the Middle Jurassic of Inner Mongolia, China // Acta Palaeontologica Polonica. Vol.54. No.3. P.557-560.

Wang Y.J., Liu Z.Q., Ren D., Shih C. 2010. A new genus of Protosmylinae from the Middle Jurassic of China (Neuroptera: Osmylidae) // Zootaxa. Vol.2480. P.45-53.

Wang Y., Liu Z., Ren D., Shih C. 2011. New Middle Jurassic kempynin osmylid lacewings from China // Acta Palaeontologica Polonica. 2011. Vol.56. No.4. P.865-869.

Yang Q., Makarkin V.N., Ren D. 2010. Remarkable New Genus of Gumillinae (Neuroptera: Osmylidae) from the Jurassic of China // Annals of the Entomological Society of America. Vol.103. No.6. P.855-859 